\title{
Presentation of Hepatocelluler carcinoma at time of discovery in Egyptian Patients with Liver Cirrhosis secondary To Chronic Hepatitis C
}

\author{
Mohammed M. Tawfik ${ }^{(1)}$,Ahmed A.Gomaa ${ }^{(2)}$, Essam A.Hassan $^{(3)}$,Eman G.Fouad $^{(4)}$ \\ (1) Professor of Tropical Medicine,Faculty of Medicine ,Beni-Suef University. \\ (2) Professor of Tropical Medicine,Faculty of Medicine,Fayoum University. \\ (3) Lecturer of Tropical Medicine ,Faculty of Medicine,Fayoum University. \\ (4) Master degree of Tropical Medicine ,Fayoum University.
}

Corresponding auther :Dr.Eman Gamal Fouad.

E-mail address :dremangamal26@gmail.com.

Tel :01224138721.

\begin{abstract}
\section{Background:}

Hepatocellular carcinoma (HCC) has an increasing incidence worldwide, It is the second most common cancer in men and the 6th most common cancers in women. In Egypt the incidence of $\mathrm{HCC}$ in the past 10 years has been doubled.
\end{abstract}

\section{Aim of the work:}

we aimed in this work to Identify presentations of patients with hepatocelluler carcinoma at time of discovery in Egyptian Patients with Liver Cirrhosis secondary To Chronic Hepatitis C in Fayoum ,Beni-suef.

\section{Keywords:}

HCC :hepatocelluler carcinoma AFP:alfa fetoprotein $\mathrm{HCV}$ :hepatitis $\mathrm{C}$ virus

\section{Introduction:}

Hepatocellular carcinoma (HCC) is a primary tumor of the liver, which usually develops in the setting of chronic liver disease, particularly in patients with chronic hepatitis B and C.HCC has become the second most prevalent cancer among men in Egypt. HCC has a rising incidence in Egypt mostly due to high prevalence of viral hepatitis and its complications.[ Baghdady, et al. ,2014]

Seventy Six \% of patients with hepatocellular carcinoma presented to their clinic with abdominal distention or discomfort; less common presentations included weight loss $(4.4 \%)$, gastrointestinal hemorrhage (4.4\%), and jaundice (2.6\%). Two \% were asymptomatic. Rarely, hepatocellular carcinoma can present as an acute abdomen resulting from spontaneous rupture of the tumor into the peritoneal cavity.

Hepatocellular carcinoma should be considered in the differential diagnosis of hemorrhagic ascites.

[ Bruix , et al. , 2012] 
Early detection of $\mathrm{HCC}$ is the most important factor to offer the patient the chance of cure.Both ultrasonography an alpha-

Fetoprotein testing have a low sensitivity for detecting HCC, although a combination of the two investigations can increase sensitivity

\section{Patients and Methods:-}

This study was conducted on 100 patients with Hepatocelluler carcinoma on top of liver cirrhosis secondary to chronic HCV Infection in Fayoum and Beni-Suef governorates in six months .

\section{Results}

\section{$\underline{\text { Socio- demographic characteristicsof study participants }(N=100)}$}

\begin{tabular}{|l|l|l||}
\hline Variable & Mean \pm SD & Range \\
\hline Age (years) & $58.3 \pm 6.9$ & $43-76$ \\
\hline Variable & $\mathrm{N}$ & $\%$ \\
\hline Sex: & 69 & 69.0 \\
Male & 31 & 31.0 \\
\hline Female & & 50.0 \\
\hline Fayoum & 50 & 50.0 \\
\hline Beni-suef & 50 & \\
\hline
\end{tabular}

A total of 100 patients were enrolled in this study .All patients had hepatocelluler carcinoma on top of chronic HCV infection and liver cirrhosis in Fayoum and Beni-suef governorates.

In our study 69 patients (69\%) were men and 31 patients $(31 \%)$ were women .

In our study the mean age was 58.3 ranging from 43 to 76 years.

In our study 50 patients(50\%) from Fayoum governorate, and 50 patients (50\%) from Beni suef governorate .

Clinical presentations among study participants in descending manner $(\mathrm{N}=100)$ 


\begin{tabular}{|l|l|l|}
\hline Variable & N & $\%$ \\
\hline Abdominal pain & 61 & 61.0 \\
\hline Accidentally discovered & 58 & 58.0 \\
\hline Anorexia & 42 & 42.0 \\
\hline Loss of weight & 31 & 31.0 \\
\hline Jaundice & 29 & 29.0 \\
\hline Abdominal swelling & 12 & 12.0 \\
\hline
\end{tabular}

In our study 61 patients (61\%) presenting with Abdominal pain ,58 patients(58\%) accidentally discovered during follow up of patients with liver cirrhosis secondary to chronic HCV infection, 42 patients(42\%) presenting with anorexia ,31 patients (31\%) presenting with loss of weight ,29 patients (29\%) presenting with jaundice ,12 patients (12\%) presenting with abdominal swelling.

\section{Clinical examination among study participants in descending manner $(\mathrm{N}=100)$}

\begin{tabular}{|l|c|c|}
\hline \multicolumn{1}{|c|}{ Variable } & $\mathrm{N}$ & $\%$ \\
\hline Splenomegaly & 78 & 78.0 \\
\hline Hepatomegaly & 57 & 57.0 \\
\hline Shrunken liver & 33 & 33.0 \\
\hline Abdominal mass & 17 & 17.0 \\
\hline Ascites & 10 & 10.0 \\
\hline L.L edema & 7 & 7.0 \\
\hline
\end{tabular}

In our study on clinical examination, 78 patients (78\%) had splenomegaly ,57 patients $(57 \%)$ had hepatomegaly ,33 patients (33\%) had shrunken liver ,17 patients(17\%) had abdominal mass, 10 patients $(10 \%)$ had ascites, 7 patients( $7 \%$ ) had lower limb oedema 


\section{Characteristics of study participants according to laboratory investigations}

\section{$\underline{(\mathrm{N}=100)}$}

\begin{tabular}{|l||c|c||}
\hline \multicolumn{1}{|c|}{ Variable } & Mean \pm SD & Range \\
\hline$\underline{\text { HB: }}$ & $10.13 \pm 1.11$ & $6.5-12$ \\
\hline \hline Platelets: & $127.67 \pm 39.26$ & $66-200$ \\
\hline \hline$\underline{\text { WBCs: }}$ & $7.84 \pm 3.32$ & $1.30-16.32$ \\
\hline \hline$\underline{\text { AST: }}$ & $113.86 \pm 51.80$ & $34.36-300.00$ \\
\hline$\underline{\text { ALT: }}$ & $87.81 \pm 49.66$ & $12.99-230.00$ \\
\hline \hline$\underline{\text { ALP: }}$ & $213.40 \pm 59.14$ & $123.00-435.00$ \\
\hline$\underline{\text { Serum bilirubin: }}$ & $2.00 \pm 0.85$ & $0.89-5.00$ \\
\hline$\underline{\text { Serum albumin: }}$ & $3.36 \pm 0.56$ & $2.00-4.50$ \\
\hline$\underline{\text { INR: }}$ & $1.59 \pm 0.56$ & $1.00-3.00$ \\
\hline \hline
\end{tabular}

In our study, mean value of hemoglobin was 10.13 \pm 1.11 ranging from 6.5 to 12 , mean value of platelets was $127.67 \pm 39.26$ ranging from 66 to 200 ,mean value of WBCs was $7.84 \pm 3.32$ ranging from 1.30 to 16.32 .

In our study mean value of ALT was $87.81 \pm 49.66$ ranging from 12.99 to 230 , mean value of AST was $113.86 \pm 51.80$ ranging from 34.36 to 300 ,mean value of ALP was $213.40 \pm 59.14$ ranging from 123 to 435 .

In our study mean value of serum bilirubin was $2.00 \pm 0.85$ ranging from 0.89 to 5 , mean value of serum albumin $3.36 \pm 0.56$ ranging from 2 to 4.5 , mean value of INR was $1.59 \pm 0.56$ ranging from 1 to 3 .

\section{Characteristics of AFP $(\mathrm{N}=100)$}

\begin{tabular}{|c|c|c|}
\hline Variable & $\overline{\mathrm{N}}$ & $\%$ \\
\hline AFP: & & \\
\hline$<10$ & 18 & 18.0 \\
\hline $10-100$ & 42 & 42.0 \\
\hline $100-200$ & 15 & 15.0 \\
\hline$>200$ & 25 & 25.0 \\
\hline
\end{tabular}

In our study ,18 patients(18\%) had AFP less than 10, 42 patients(42\%) had AFP ranging from 10 to 100, 15 patients (15\%) had AFP ranging from 100 to 200, 25 patients (25\%) had AFP more than 200. 
In our study,radiological characteristics of HFL were,mean number of HFL was 2.0 \pm 1.0 ranging from 1 to 4,50 patients (50\%) had right lobe HFL , 19 patients (19\%) had left HFL, 31 patients (31\%) had HFL in both hepatic lobes.

\section{$\underline{\text { U/S characteristics of HFL }(\mathrm{N}=100)}$}

\begin{tabular}{|l|c|c|}
\hline \multicolumn{1}{|c|}{ Variable } & Mean \pm SD & Range \\
\hline Number of HFL & $2.0 \pm 1.0$ & $1-4$ \\
\hline \hline \multicolumn{1}{|c|}{ Variable } & $\mathrm{N}$ & $\%$ \\
\hline Site: & 50 & \\
Right & 19 & 50.0 \\
Left & 31 & 19.0 \\
Both & & 31.0 \\
\hline Size: & 32 & 32.0 \\
$<3 \mathrm{~cm}$ & 35 & 35.0 \\
$3-5 \mathrm{~cm}$ & 29 & 29.0 \\
$5-7 \mathrm{~cm}$ & 4 & 4.0 \\
$>7 \mathrm{~cm}$ & & \\
\hline
\end{tabular}

\section{$\underline{\text { Other radiological features in descending manner }(\mathrm{N}=100)}$}

\begin{tabular}{|l|c|c|}
\hline \multicolumn{1}{|c|}{ Variable } & $\mathrm{N}$ & $\%$ \\
\hline Splenomegaly & 84 & 84.0 \\
\hline Hepatomegaly & 58 & 58.0 \\
\hline Shrunken liver & 33 & 33.0 \\
\hline \hline Ascites & 17 & 17.0 \\
\hline PVT & 10 & 10.0 \\
\hline Abdominal L.N & 13 & 13.0 \\
\hline
\end{tabular}

In our study, in radiological examination, 84 patients (84\%) had splenomegaly,58 patients (58\%) had hepatomegaly,33 patients (33\%) had shrunken liver,17 patient (17\%) had ascites ,10patients (10\%) had PVT ,13 patient (13\%) had abdominal lymphadenopathy.

In our study,BCLC staging of the patients, 46 patients (46\%) ware stage A ,28 patients were stage B ,10 patients (10\%) were stage C ,16 patients (16\%) were stage D.

In our study ,Child classification of the patients, 48 patients (48\%) were child A ,36 patients (36\%) were child B ,16 patients(16\%) were child C. 


\section{Characteristics of study participants according to BCLC staging \&Child}

\section{classification $(\mathrm{N}=100)$}

\begin{tabular}{|l|c|c||}
\hline \multicolumn{1}{|c|}{ Variable } & $\mathrm{N}$ & $\%$ \\
\hline \hline BCLC staging: & 46 & 46.0 \\
Stage A & 28 & 28.0 \\
Stage B & 10 & 10.0 \\
Stage C & 16 & 16.0 \\
Stage D & & \\
\hline Child Classification: & 48 & 48.0 \\
Child A & 36 & 36.0 \\
Child B & 16 & 16.0 \\
Child C & & \\
\hline
\end{tabular}

\section{Discussion}

Hepatocellular carcinoma (HCC) is one of the common primary malignant tumours of the liver.It is the second most common cancer in men and the 6th most common cancers in women. In Egypt the incidence of HCC in the past 10 years has been doubled.[Azab,et al. , 2011]

The goal of surveillance and screening is to reduce mortality. $\mathrm{HCC}$ meets the criteria for the development of a surveillance program given that patients with cirrhosis are a highrisk group and they can be readily identified.[ Singal ,et al. ,2014]

\section{Conclusion}

Hepatocellular carcinoma (HCC) is one of the common primary malignant tumours of the liver. It is the second most common cancer in men and the 6th most common cancers in women. In Egypt the incidence of HCC in the past 10 years has been doubled. It is estimated that the prevalence of $\mathrm{HCC}$ will increase in Egypt, reaching its peak this year 2018 .

Symptoms and signs of cirrhosis are often the only expression of the disease. The goal of surveillance and screening is to reduce mortality. HCC meets the criteria for the development of a surveillance program given that patients with cirrhosis are a high-risk group and they can be readily identified for early diagnosis of HCC.

Surveillance programs with the purpose of early detection of HCC, primarily through serum markers as alpha-fetoprotein (AFP) assessment and hepatic imaging, have led to archive to early diagnosis and curative treatment in patients with HCC.

\section{References}


- Abdel-Rahman OM, Elsayed

Z,M,shaker(2016).Yttrium-90

microsphere radioembolisation for unresectable hepatocellular carcinoma.

Cochrane Database of Systematic

Reviews.(2):1-31.

doi:10.1002/14651858.cd011313.pub2.

- Azab.M, Zaki .S, El-Shetey .A, Abdel-Moty .M, Alnoomani .N, Gomaa .A, Abdel-fatah .S, Mohiy .S, Atia .F (2011)Radiofrecquency ablation combined with percutanous ethanol injection in patients with HCC. Arab Journal of Gastroentrology; 12: 113-118.

- Baghdady I, Fouad F, Sayed M, et al,(2014) Serum markers for the early detection of hepatocellular carcinoma in patients with chronic viral hepatitis C infection. Menoufia Med J ;27:744750 .

- Bruix J, Raoul JL, Sherman M, et al,(2012).Efficacy and safety of sorafenib in patients with advanced hepatocellular carcinoma: subanalyses of a phase III trial. J Hepatol ;57:821-9.

- Bruix J, Gores GJ, Mazzaferro V(2014).Hepatocellular carcinoma:clinical frontiers and perspectives. Gut; 63: 844-855 [PMID:24531850 DOI: 10.1136/gutjnl2013-3066

- Bruix J, Sherman M. Management of hepatocellular carcinoma: anupdate. Hepatology (2011);53: 1020-1022 [PMID: 21374666 DOI:10.1002/hep.24199]

- Bruix J, Takayama T, Mazzaferro V, Chau G-Y, Yang J, Kudo M, et al(2015).Adjuvant sorafenib for hepatocellular carcinoma after resection or ablation (STORM): a phase 3, randomised, doubleblind,placebo-controlled trial. The
Lancet Oncology;16(13):1344-54. doi: 10.1016/s1470-2045(15)00198-9.

- Bujold A, Massey CA, Kim JJ, Brierley J, Cho C, Wong RK, et al(2013 May). Sequential phase I and II trials of stereotactic body radiotherapy for locally advanced hepatocellular carcinoma. J Clin Oncol 1;31(13):1631-1639 PubMed ID 23547075 .

- Chaiteerakij R, Addissie BD, Roberts LR(2015).Update on biomarkers of hepatocellular carcinoma. Clin Gastroenterol Hepatol;13(2):237-45.

- Chen K, Ou TM, Hsu CW, Horng CT, Lee CC, Tsai YY, et al(2015).Current systemic treatment of hepatocellular carcinoma: A review of the literature. World $\mathbf{J}$ Hepatol;7(10):1412-20. doi:10.4254/wjh.v7.i10.1412.

- Chen F, Xue J, Zhou L, Wu S, Chen $\mathbf{Z}$ (2011). Identification of serum biomarkers of hepatocarcinoma through liquid chromatography/mass spectrometry-based metabonomic method. Anal BioanalChem; 401: 1899-1904 [PMID: 21833635 DOI: $10.1007 / \mathrm{s} 00216-011-5245-3]$

- Conti F, Buonfiglioli F, Scuteri A, Crespi C, Bolondi L, Caraceni P, et al(2016).Early occurrence and recurrence of hepatocellular carcinoma in HCV-related cirrhosis treated with direct-acting antivirals.JournalofHepatology;65(4):7 27-33.doi: 10.1016/j.jhep.2016.06.015.

- Darnell A, Forner A, Rimola J, Reig M, Garcia-Criado A, Ayuso C, et al(2015). Liver Imaging Reporting and Data System with MR Imaging: Evaluation in Nodules $20 \mathrm{~mm}$ or Smaller Detected in Cirrhosis at 
Screening US. Radiology;275(3):698707. doi: 10.1148/radiol.15141132.

- El-Serag HB and Kanwal $\mathbf{F}(\mathbf{2 0 1 4})$.Epidemiology of hepatocellular carcinomain the United States: Where are we? Where do we go? Hepatology; 60: 1767-1775 [PMID: 24839253 DOI: 10.1002/hep.27222]

- Forner A, Llovet JM, Bruix J(2012); Hepatocellular carcinoma. Lancet.2012 Mar31;379(9822):124555. Epub2012 Feb 20.

- Hsiang JC, Wong GL-H, Tse Y-K, Wong VW-S, Yip TC-F, Chan HLY(2015Huo YR, Eslick GD(2015).Transcatheter Arterial Chemoembolization Plus Radiotherapy Compared With Chemoembolization Alone for Hepatocellular Carcinoma. JAMA Oncology;1(6):756. doi:10.1001/jamaoncol.2015.2189.

- Ha M, Kim VN(2014). Regulation of microRNA biogenesis. Nat RevMol Cell Biol; 15: 509-524 [PMID: 25027649 DOI: 10.1038/nrm3838].

- Hadziyannis E, Sialevris K, Georgiou A, Koskinas $\mathbf{J}(\mathbf{2 0 1 3})$. Analysis ofserum $\alpha$ fetoprotein-L3\% and des- $\gamma$ carboxyprothrombin markers incases with misleading hepatocellular carcinoma total $\alpha$-fetoproteinlevels. Oncol Rep; 29: 835-839[PMID: 23174906 DOI:10.3892/or.2012.2147]

- Johnson PJ, Pirrie SJ, Cox TF, Berhane S, Teng M, Palmer D, MorseJ, Hull D, Patman G, Kagebayashi C, Hussain S, Graham J, ReevesH, Satomura S(2014). The detection of hepatocellular carcinoma using aprospectively developed and validated model based on serological biomarkers. Cancer Epidemiol Biomarkers Prev ; 23: 144-153[PMID: 24220911 DOI: 10.1158/10559965.EPI-13-0870].

- Kannan RP, Hensley LL, Evers L, et al. Hepatitis $C$ virus infection causes cell cycle arrest at the level of entry to mitosis. J Virol. 2011;85:7989-8001.

- Link A, Goel A(2013).MicroRNA in gastrointestinal cancer: a step closerto reality. Adv Clin Chem; 62: 221-268 [PMID: 24772669DOI: 10.1016/B9780-12-800096-0.00006-8]

- Liu CC, Wang YH, Chuang EY, Tsai MH, Chuang YH, Lin CL,Liu CJ, Hsiao BY, Lin SM, Liu LY, Yu MW(2014). Identification of a liver cirrhosis signature in plasma for predicting hepatocellular carcinoma risk in a population-based cohort of hepatitis B carriers.Mol Carcinog; 53: 58-66 [PMID: 22911910 DOI: $10.1002 / \mathrm{mc} .21952]$

- Makarova-Rusher OV, Altekruse SF, McNeel TS, Ulahannan S, Duffy AG, Graubard BI, et al(2016).Population attributable fractions of risk factors for hepatocellular carcinoma in the United States.Cancer;122(11):1757-65. doi: 10.1002/cncr.29971.

- Maluccio .M and Covey A (2012)Recent Progress in Understanding, Diagnosis and Treating Hepatocellular Carcinoma . Cancer J. Clin. ; 1-6 .

- Manini MA, Sangiovanni A, Fornari F, Piscaglia F, Biolato M, Fanigliulo L, et al(2014). Clinical and economical impact of 2010 AASLD guidelines for the diagnosis of hepatocellular carcinoma. Journal of Hepatology;60(5):995-1001. doi: 10.1016/j.jhep.2014.01.006. 
- McGivern DR, Lemon SM.Virusspecific mechanisms ofcarcinogenesis in hepatitis $C$ virus associated livercancer. Oncogene. 2011;30:196983.

- Mohamoud YA, Mumtaz GR, Riome S, Miller D, Abu-Raddad LJ(2013). The epidemiology of hepatitis $\mathrm{C}$ virus in Egypt: a systematic review and data synthesis. BMC Infect Dis; 13:288.

- Naglaa A. El Sherbinya, Zaky .S, Gomma .A, Hassan .E, Atta .N( 2017),Epidemiology of HCC in Fayoum governorate,Egypt. International Journal of Sciences: Basic and Applied Research (IJSBAR) (2017) Volume 33, No 1, pp 21-32.

- Nakamoto Y, Guidotti LG, Kuhlen CV, et al. Immune Pathogenesis of hepatocellular carcinoma. J Exp.Med. 1998; $188: 341-350$

- Petrick JL, Braunlin M, Laversanne M, Valery PC, Bray F, McGlynn KA(2016).International trends in liver cancer incidence, overall and by histologic subtype, 1978-2007. International Journal of Cancer;139(7):1534-45. doi: 10.1002/ijc.30211.

- Petrick JL, Kelly SP, Altekruse SF, McGlynn KA, Rosenberg PS(2016).Future of Hepatocellular Carcinoma Incidence in the United States Forecast Through 2030. Journal of Clinical Oncology.;34(15):1787-94. doi: 10.1200/jco.2015.64.7412.

- Qiu W, Wang X, Leibowitz B, et al. PUMA-mediated apoptosis drives chemical hepatocarcinogenesis in mice. Hepatology. 2011;54:1249-58.
- Schütte K, Bornschein J, Kahl S, Seidensticker R, Arend J, Ricke J(2012), Malfertheiner P Delayed diagnosis of HCC with chronic alcoholic liver disease. Liver Cancer; 1:257-266.

- Singal AG, Pillai A, Tiro J(2014). Early Detection, Curative Treatment, and Survival Rates for Hepatocellular Carcinoma Surveillance in Patients with Cirrhosis: A Meta-analysis. PLoS Med;11(4):e1001624. doi: 10.1371/journal.pmed.1001624.

- Shin SK, Kim YS, Choi SJ, Shim YS, Jung DH, Kwon OS, et al (2015).Contrast-enhanced ultrasound for the differentiation of small atypical hepatocellular carcinomas from dysplastic nodules in cirrhosis.

Digestive and Liver Disease;47(9):77582. doi: 10.1016/j.dld.2015.05.001.

- Smith R. Screening Fundamentals. J Natl Cancer Inst Monogr.(2015);1997(22):15-9.Cole P, Morrison AS. Basic issues in population screening for cancer. J Natl Cancer Inst.1980;64(5):1263-72.

- Tanabe M, Kanki A, Wolfson T, Costa EAC, Mamidipalli A, Ferreira MPFD, et al(2016).Imaging Outcomes of Liver Imaging Reporting and Data System Version 2014 Category 2, 3, and 4 Observations Detected at CT and MR Imaging. Radiology. ;281(1):152173. doi: 10.1148/radiol.2016152173.

- Tao SM, Wichmann JL, Schoepf UJ, Fuller SR, Lu GM, Zhang LJ(2016).Contrast-induced nephropathy in CT: incidence, risk factors and strategies for prevention. Eur Radiol;26(9):3310-8. doi: 10.1007/s00330-015-4155-8. 
- Tanabe M, Kanki A, Wolfson T, Costa EAC, Mamidipalli A, Ferreira MPFD, et al(2016). Imaging

Outcomes of Liver Imaging Reporting and Data System Version 2014
Category 2, 3, and 4 Observations Detected at $\mathrm{CT}$ and MR Imaging. Radiology. ;281(1):152173. doi: 10.1148/radiol.2016152173. 